Creative Commons User License: CC BY-NC-ND

Abstracted by: EBSCOhost, Electronic Journals Service (EJS), Google Scholar, Journal Seek, Scientific Commons,

Food and Agricultural Organization (FAO), CABI and Scopus

http://eoi.citefactor.org/10.11226/v24i3
Journal of Agricultural Extension

Vol. 24 (3) July, 2020

ISSN(e): 24086851; ISSN(Print); 1119944X

http://journal.aesonnigeria.org

http://www.ajol.info/index.php/jae

Email: editorinchief@aesonnigeria.org

\title{
Climate Change Adaptation Practices and Rice Farmers' Level of Living in North-West, Nigeria
}

https://dx.doi.org/10.4314/jae.v24i3.5

\section{Yakubu, Danlami Haruna}

Department of Agricultural Extension and Rural Development, Usmanu Danfodiyo University, Sokoto.

Email: danlami y@yahoo.com

Phone Number: +234(0)8069064617

\section{Akpoko, Joseph Gambo}

Department of Agricultural Extension and Rural Development,

Ahmadu Bello University, Zaria.

Email: josephgamboakpoko@gmail.com

Phone: +2348033973686

\section{Akinola, Mathew Oluwatuyi}

Department of Agricultural Extension and Rural Development,

Ahmadu Bello University, Zaria.

Email: moluakin59@yahoo.com

Phone: +2347067694919

\author{
Abdulsalam, Zakari \\ Department of Agricultural Economics, \\ Ahmadu Bello University, Zaria. \\ Email: zakabd2009@gmail.com \\ Phone: +2348176445874
}

\section{Abstract}

The study examined the effect of climate change adaptation practices on rice farmers' level of living in North-West, Nigeria. It targeted Sokoto, Kebbi and Zamfara States in the North-West, Nigeria that are among the major rice producing States in the country. A multistage sampling procedure was used to obtain a sample of 522 farmers for the study. The data were obtained with the aid of structured interview schedule were analysed using both descriptive (frequency counts, percentages, ranges and means) and inferential (Chisquare) statistics. Findings of the study reveal that the majority (96\%) of the respondents had their income from rice production, within the A50,000.00 to $\mathrm{A} 499,999.00$ (143 to 1,429 USD) range. The mean rice income was $\mathrm{A} 308,742.00$ (882 USD). The majority (84.48\%) and (77.40\%) of the respondents used improved rice varieties and intercropping as climate change adaptation practices, respectively. Other climate change adaptation practices used by the rice farmers included moderate use of fertilizers (93.10\%) and other chemicals (89.85\%), as well as use of organic manure (99.43\%). The farmers also adjusted the planting calendar through early planting (92.34\%) and early harvesting (93.10\%). Similarly, the majority (89.85\%) of the respondents made mounds and ridges across slopes while 
Creative Commons User License: CC BY-NC-ND

Abstracted by: EBSCOhost, Electronic Journals Service (EJS), Google Scholar, Journal Seek, Scientific Commons,

Food and Agricultural Organization (FAO), CABI and Scopus

http://eoi.citefactor.org/10.11226/v24i3
Journal of Agricultural Extension

Vol. 24 (3) July, 2020

ISSN(e): 24086851; ISSN(Print); 1119944X

http://journal.aesonnigeria.org

http://www.ajol.info/index.php/jae

Email: editorinchief@aesonnigeria.org

96.17\% and $89.08 \%$ used rivers/streams and dug wells for irrigation. About $51 \%$ of the rice farmers spent $\mathrm{N5}, 000.00$ - $\mathrm{N} 370,999.00$ of their rice income on vehicles. $54 \%$ spent $\mathrm{A} 8,000.00$ - $\mathrm{A} 92,299.00$ of their rice income on electronics and only about 14\% spent $\$ 4,000.00$ - $\$ 102,999.00$ of their rice income on land and housing. There was a significant $\left(X^{2}=258.6325 ; p<\right.$ 0.00) relationship between farmers' use of climate change adaptation practices and their level of living. The study concluded that rice farmers' use of climate change adaptation practices could lead to improvement in their rice income and level of living.

Keywords: Climate change, Adaptation practices, Rice farmers, Level of living

\section{Introduction}

Agriculture is the major source of livelihood in many African countries especially for the vulnerable rural people who face lots of challenges that hamper agricultural productivity. In recent years, climate change is considered as a major challenge to agriculture, particularly in developing countries. Poor and marginalized communities in these countries are expected to be the most vulnerable to climate change and its impacts, due to their limited capacity for adaptation and heavy dependence on natural resources (Ho and Shimada, 2018). Approximately 2.5 billion people who derive their livelihoods in partly or in totally from agricultural production are affected by climate change (Ali et al., 2017).

Climate change influences productivity and production in agricultural sectors in a manner that will result primarily in negative socio-economic impacts (Lewis et al., 2018). For instance, sustainable rice production and consumption are central factors in meeting food security of poor people in developing countries. However, the magnitude of the changes that are likely to take place due to incidences of climate change in developing countries is not well investigated (Arimi, 2014). Climate change impacts negatively on both production and livelihoods of the rice farmers in NorthWest, Nigeria.

To mitigate climate change and its adverse impacts, adaptation is considered to be an important response (Ho and Shimada, 2018). Human response to climate change is critical to understanding and estimating the level of use of adaptation strategies employed by the farmers to mitigate the effect of climate change on crop production (Akintonde et al., 2016).

Farmers' physical assets can be used in assessing their level of living. Households that have few assets but benefit from an income above the poverty line are particularly vulnerable to climate change impacts. Asset ownership is often used as a key welfare indicator. Asset acquisition may reflect an improvement in living standards and vice versa.

This study was carried out to assess the effects of climate change adaptation practices on rice farmers' level of living in North-West, Nigeria. It specifically 
Creative Commons User License: CC BY-NC-ND

Abstracted by: EBSCOhost, Electronic Journals Service (EJS), Google Scholar, Journal Seek, Scientific Commons,

Food and Agricultural Organization (FAO), CABI and Scopus
Journal of Agricultural Extension

Vol. 24 (3) July, 2020

ISSN(e): 24086851; ISSN(Print); 1119944X

http://journal.aesonnigeria.org

http://www.ajol.info/index.php/jae

Email: editorinchief@aesonnigeria.org

determined the farmers' use of climate change adaptation practices and determined the relationship between the farmers' use of climate change adaptation practices and their level of living.

\section{Methodology}

The study was conducted in three States namely: Kebbi, Sokoto and Zamfara of North-West zone, Nigeria. The zone is located between latitude $9^{0} 10^{1} \mathrm{~N}$ and $13^{0} 50^{1} \mathrm{~N}$ and longitude $3^{0} 35^{1} \mathrm{E}$ and $9^{0} 00^{1} \mathrm{E}$ and it covers about $168,719 \mathrm{~km}^{2}$. The zone also consists of Jigawa, Kaduna, Kano, Kebbi, Sokoto and Zamfara States. It has a projected population of 46,694,805 million people (National Population Commission (NPC), 2015).

The vegetation consists of Northern Guinea Savannah and Sudan Savannah, a vegetation belt covering most parts of the zone stretching from the Sokoto plains in the west, through the northern sections of the central highland. There is a low annual rainfall of usually less than $1000 \mathrm{~mm}$ and a prolonged dry season (6-9 months) which sustains fewer trees and shorter grasses than the Southern Guinea Savannah. It is characterized by abundant short grasses of about $1.5-2 \mathrm{~m}$ and few stunted trees hardly above $15 \mathrm{~m}$. It is by far the most densely human populated zone of northern Nigeria. Thus, the vegetation has undergone a severe destruction in the process of clearing land for the cultivation of important economic crops such as cotton, millet, maize and wheat. This is in addition to the devastation due to animal husbandry, especially cattle rearing, which is greatly favoured in this belt because the area is relatively free from tsetse fly. The trees of the Sudan Savannah include the acacia, the shea-butter, baobab and the silk cotton (Yakubu, Abubakar, Atala, Muhammed, and Abdullahi, 2013).

A multistage sampling procedure was used to select the population for the study. In the first stage, three states, Sokoto, Kebbi and Zamfara States were purposively selected in the North-West zone because they are among the major rice producing states in the country and the region in particular. In the second stage, 4, out of the 20 major rice producing LGAs, were purposively selected in Kebbi State based on high population of the rice farmers; 3 out of 14 LGAs in Sokoto and 2 out of 12 LGAs in Zamfara States. This gave 9 out of 46 LGAs (20\%) in the 3 States. The LGAs chosen from Kebbi State included Augie, Dandi, Birnin Kebbi and Suru. Those from Sokoto State included Goronyo, Wurno and Silame while those from Zamfara State were Bakura and Talata Mafara.

The third stage was a purposive selection of 16 villages out of $286(5 \%)$, also based on high population of the rice farmers, from the villages. In the third stage 522 farmers $(3 \%)$ out of 17,071 (sampling frame) were randomly chosen from the selected villages to give the study sample.

Data for the study was collected with the aid of structured interview schedule and were analysed using both descriptive and inferential statistics. Descriptive statistics such as frequency counts, percentages, ranges and mean were used to describe the 
Creative Commons User License: CC BY-NC-ND

Abstracted by: EBSCOhost, Electronic Journals Service (EJS), Google Scholar, Journal Seek, Scientific Commons,

Food and Agricultural Organization (FAO), CABI and Scopus

http://eoi.citefactor.org/10.11226/v24i3
Journal of Agricultural Extension

Vol. 24 (3) July, 2020

ISSN(e): 24086851; ISSN(Print); 1119944X

http://journal.aesonnigeria.org

http://www.ajol.info/index.php/jae

Email: editorinchief@aesonnigeria.org

socioeconomic characteristics of the farmers. Chi-square was used to determine the effect of climate change adaptation practices on farmers' level of living.

Chi-square model is specified as:

$X^{2}=\sum(O-E)^{2} / E$

Where:

$\mathrm{X}^{2}=$ Chi- square;

$\Sigma$ = Summation of;

$\mathrm{O}=$ Observed value of variable; and

$\mathrm{E}=$ Expected value of variable.

\section{Results and Discussion}

\section{Income from Rice Production}

Rice income refers to the earnings, returns or proceeds of cash or cash-equivalents received by the farmers from rice production. Results of the study show that the majority of the respondents, about $81 \%$ in Kebbi, $96 \%$ in Sokoto and $84 \%$ in Zamfara States had an income from rice production, within the range of $\$ 50,000.00$ to $\$ 499,999.00$ (143 to 1,429 USD). Overall, about $86 \%$ of them had their income from rice production, within the $\$ 50,000.00$ to $\$ 499,999.00$ (143 to 1,429 USD) range.

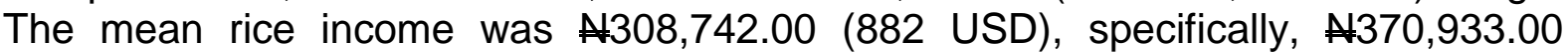
(1,060 USD), $N 239,516.00$ (684 USD) and $\$ 315,776.80$ (902 USD) for Kebbi, Sokoto and Zamfara State farmers, respectively (Table 1). This is better compared to rice income of $\$ 189,410.00$ and $\$ 201,166.00$, reported by Nwaobiala and Adesope (2013) for upland swamp rice farmers, respectively.

Table 1: Income from rice production

\begin{tabular}{lcrrrr}
\hline Variable & $\begin{array}{c}\text { Kebbi } \\
\text { State } \\
(\mathbf{n = 2 7 9}) \\
\%\end{array}$ & $\begin{array}{r}\text { Sokoto } \\
\text { State } \\
(\mathbf{n = 1 8 7}) \\
\%\end{array}$ & $\begin{array}{r}\text { Zamfara } \\
\text { State } \\
(\mathbf{n}=56) \\
\%\end{array}$ & $\begin{array}{r}\text { Pooled } \\
\text { Sample } \\
(\mathbf{n = 5 2 2}) \\
\%\end{array}$ \\
\hline $\begin{array}{l}\text { Income from } \\
\text { production (A) }\end{array}$ & rice & & & & \\
Below 50,000 & 2.15 & 0.00 & 1.79 & 1.34 \\
$50,000-499,999$ & 80.65 & 95.72 & 83.93 & 86.40 \\
$500,000-949,999$ & 10.75 & 4.28 & 14.29 & 8.81 \\
More than 949,999 & 6.45 & 0.00 & 0.00 & 3.45 \\
Mean rice income & & & & $\mathbf{3 1 5 , 7 7 6 . 8 0}$ \\
\hline
\end{tabular}

\section{Use of Climate Change Adaptation Practices}

Portfolio diversification: There are two sub-practices under this: the use of improved rice varieties and intercropping. Result of this study shows that majority of the respondents, about $89 \%$ in Kebbi State, $75 \%$ in Sokoto State and $95 \%$ in Zamfara State used improved rice varieties. Overall, $84 \%$ of them used of improved rice varieties. Similarly, a majority (about $77 \%$ ) of the respondents, with $78 \%$ in 
Creative Commons User License: CC BY-NC-ND

Abstracted by: EBSCOhost, Electronic Journals Service (EJS), Google Scholar, Journal Seek, Scientific Commons,

Food and Agricultural Organization (FAO), CABI and Scopus

http://eoi.citefactor.org/10.11226/v24i3
Journal of Agricultural Extension

Vol. 24 (3) July, 2020

ISSN(e): 24086851; ISSN(Print); 1119944X

http://journal.aesonnigeria.org

http://www.ajol.info/index.php/iae

Email: editorinchief@aesonnigeria.org

Kebbi State, $71 \%$ in Sokoto State and $98 \%$ in Zamfara State used intercropping (Table 2). This indicates that the respondents do not depend mainly on rice production; they also produce other crops to prevent a total failure of rice as a result of changes in climate. Not only are different crops grown, the respondents also carefully select the varieties that are better in terms of yield, early maturity, drought tolerance and resistance to pests and diseases. These are put into practice to adapt to climate change. Among the major climate change adaptation strategies used by rice farmers in Southwestern, Nigeria was planting improved rice varieties such as Federal Agricultural Research Oryza (FARO) (Arimi, 2014).

Table 2: Use of Climate Change Adaptation Practices

\begin{tabular}{|c|c|c|c|c|}
\hline 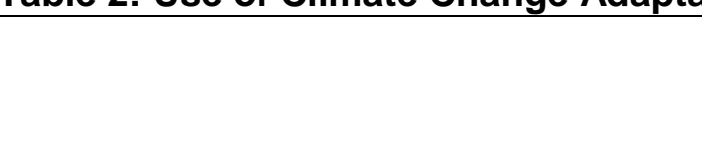 & $\begin{array}{r}\text { Kebbi } \\
\text { State } \\
(n=279)\end{array}$ & $\begin{array}{r}\text { Sokoto } \\
\text { State } \\
(n=187)\end{array}$ & $\begin{array}{r}\text { Zamfara } \\
\text { State } \\
(n=56)\end{array}$ & $\begin{array}{l}\text { Pooled } \\
\text { Sample } \\
(n=522)\end{array}$ \\
\hline Variable & $\%$ & $\%$ & $\%$ & $\%$ \\
\hline \multicolumn{5}{|l|}{ Portfolio diversification: } \\
\hline Use of improved rice varieties & 88.53 & 75.40 & 94.64 & 84.48 \\
\hline Intercropping & 77.78 & 70.59 & 98.21 & 77.40 \\
\hline \multicolumn{5}{|l|}{ Soil conservation: } \\
\hline Mulching & 44.80 & 17.20 & 35.71 & 33.91 \\
\hline Planting of cover crops & 32.62 & 19.79 & 37.50 & 28.54 \\
\hline Planting of trees & 49.46 & 33.69 & 19.64 & 40.61 \\
\hline Moderate use of fertilizers & 91.76 & 96.26 & 89.29 & 93.10 \\
\hline Moderate use of chemicals & 89.61 & 90.91 & 87.50 & 89.85 \\
\hline Use of organic manure & 100.00 & 98.93 & 98.21 & 99.43 \\
\hline \multicolumn{5}{|l|}{ Adjusting the planting calendar: } \\
\hline Early planting & 96.77 & 85.56 & 92.86 & 92.34 \\
\hline $\begin{array}{l}\text { Late planting } \\
\text { Lats }\end{array}$ & 3.58 & 14.44 & 1.79 & 7.28 \\
\hline Early harvesting & 94.98 & 89.30 & 96.43 & 93.10 \\
\hline Late harvesting & 5.38 & 10.70 & 3.57 & 7.09 \\
\hline \multicolumn{5}{|l|}{ Use of minimum tillage: } \\
\hline Zero tillage & 4.30 & 5.88 & 0.00 & 4.41 \\
\hline $\begin{array}{l}\text { Making mounds and digging ridges } \\
\text { across slopes }\end{array}$ & 93.19 & 82.89 & 96.43 & 89.85 \\
\hline \multicolumn{5}{|l|}{ Use of irrigation technologies: } \\
\hline Rainwater harvesting & 0.00 & 0.00 & 1.79 & 0.19 \\
\hline Use of rivers/streams & 97.13 & 95.19 & 94.64 & 96.17 \\
\hline Digging of well & 87.81 & 90.37 & 91.07 & 89.08 \\
\hline Sinking of bore-hole & 5.02 & 2.67 & 3.57 & 4.02 \\
\hline
\end{tabular}

${ }^{*}$ Multiple responses

Soil conservation: Mulching was used by about $45 \%$ in Kebbi State, $17 \%$ in Sokoto State, $36 \%$ in Zamfara State and $34 \%$ of the respondents all together. Planting of cover crops was used by $34 \%$ in Kebbi State, $20 \%$ in Sokoto State, $38 \%$ in Zamfara State and $29 \%$ of the respondents collectively. Also, about $41 \%$ of the respondents, with $50 \%$ in Kebbi State, $34 \%$ in Sokoto State and $20 \%$ in Zamfara State used planting of trees. 
Creative Commons User License: CC BY-NC-ND

Abstracted by: EBSCOhost, Electronic Journals Service (EJS), Google Scholar, Journal Seek, Scientific Commons,

Food and Agricultural Organization (FAO), CABI and Scopus
Journal of Agricultural Extension

Vol. 24 (3) July, 2020

ISSN(e): 24086851; ISSN(Print); 1119944X

http://journal.aesonnigeria.org

http://www.ajol.info/index.php/jae

Email: editorinchief@aesonnigeria.org

The majority of the respondents, about $92 \%$ in Kebbi State, $96 \%$ in Sokoto State and $89 \%$ in Zamfara State applied the moderate use of fertilizers. Overall, $93 \%$ of them applied the moderate use of fertilizers. Similarly, a majority of them, $90 \%$ in Kebbi State, $91 \%$ in Sokoto State and $88 \%$ in Zamfara State applied the moderate use of chemicals. Overall, $90 \%$ of them applied the moderate use of chemicals. In the same vein, a majority (about $99 \%$ ) of the respondents, with the entire respondents $(100 \%)$ in Kebbi State, $99 \%$ in Sokoto State and $98 \%$ in Zamfara State applied the use of manure (Table 2). This implies that the only aspects of soil conservation largely used by the farmers were moderate use of fertilizers, moderate use of chemicals and use of organic manure.

Erbas and Solakoglu (2017) reported a link between nitrogen fertilizer use and the land annual mean temperature anomalies arising from climate change, incorporating the effect of income and agriculture share to understand better their impact on emissions from agricultural activities along climate indicators. They added that in the long-run, the causality is significant and unidirectional, indicating that income, agriculture share, and land temperature anomalies cause agricultural emissions, and that disequilibrium from such emissions cannot be eliminated within a year and in the short-run, effective use of nitrogen fertilizers and other associated agricultural practices can be achieved.

Adjusting the planting calendar: The majority of the respondents, about $97 \%$ in Kebbi State, $86 \%$ in Sokoto State and $93 \%$ in Zamfara State used early planting. Overall, about $93 \%$ of them had used early planting. Similarly, the majority of the respondents, $95 \%$ in Kebbi State, $89 \%$ in Sokoto State and 96\% in Zamfara State used early harvesting. Overall, about $93 \%$ of them had used early harvesting.

Late planting was used by only about $4 \%$ in Kebbi State, $14 \%$ in Sokoto State, $3 \%$ in Zamfara State and $7 \%$ of the respondents all together. Similarly, late harvesting was used by only about $5 \%$ in Kebbi State, $11 \%$ in Sokoto State, $4 \%$ in Zamfara State and $7 \%$ of the respondents all together (Table 2). This indicates that early planting and early harvesting were the main components of adjusting planting calendar used widely by the rice farmers. Akintonde et al. (2016) reported that the most highly used climate change adaptation strategies by crop farmers in Oyo and Ekiti States, Nigeria include; cultivation of improved varieties and altering of planting date among others.

Use of minimum tillage: The majority of the respondents, about $93 \%$ in Kebbi State, $83 \%$ in Sokoto State and $96 \%$ in Zamfara State had used the practice of making mounds and ridges across slopes. Overall, about $90 \%$ of them had used the practice of making mounds and digging ridges across slopes. However, zero tillage was used by only about $4 \%$ in Kebbi State, $6 \%$ in Sokoto State, none in Zamfara State and $4 \%$ of the respondents all together (Table 2). This indicates that making mounds and digging ridges across slopes was well used by the respondents in their efforts to adapt to climate change. 
Creative Commons User License: CC BY-NC-ND

Abstracted by: EBSCOhost, Electronic Journals Service (EJS), Google Scholar, Journal Seek, Scientific Commons,

Food and Agricultural Organization (FAO), CABI and Scopus
Journal of Agricultural Extension

Vol. 24 (3) July, 2020

ISSN(e): 24086851; ISSN(Print); 1119944X

http://journal.aesonnigeria.org

http://www.ajol.info/index.php/jae

Email: editorinchief@aesonnigeria.org

Reducing tillage and maintaining soil cover with crop residues can reduce erosion by up to $80 \%$. No-till usually increases the concentration of organic matter near the soil surface. However, some of the observed increase is a redistribution of organic carbon, not a net accumulation-extra organic carbon occurs near the surface but not always in deeper soil (Richards et al., 2014). Hence, no-till has the potential to mitigate climate change, increase rice yield and improve the farmers' level of living.

Use of irrigation technologies: The use of rivers/streams as sources of water was used by majority of the respondents, about $97 \%$ of them in Kebbi State, $95 \%$ in Sokoto State and $95 \%$ in Zamfara State. Overall, $96 \%$ of them used rivers/streams as source of water for irrigation. Digging of wells for water supply was similarly used by the majority (about $89 \%$ ) of the respondents, $88 \%$ of them in Kebbi State, $90 \%$ in Sokoto State and $91 \%$ in Zamfara State.

There was a very minimal use of rainwater harvesting and sinking of bore-holes among the farmers (Table 2). This implies that the farmers mainly used rivers/streams and dug wells for irrigation. This is contrary to the finding of Abaje et al. (2014) who reported that the most significant climate change adaptation strategies used by farmers were water harvesting, use of fertilizer/animals' dung to improve soil moisture and prayers for God to intervene.

Adebayo et al. (2012) examined farmers' awareness, vulnerability and adaptation to climate change in Adamawa State, Nigeria and reported that farmers used seed tolerant varieties, altered their planting schedule, planted early maturing seed, used different tillage systems, and diversified their crops. They concluded that farmers adapted different adaptive measures to minimize the effect of climate change in the area.

In a study to determine the farmers' adaptation strategies to climate change and their implications in the Zou Department of South Benin, Fadina and Barjolle (2018) reported that the majority of farmers were using different adaptation strategies to reduce the negative impact of climate change including crop-livestock diversification and other good practices (mixed cropping, crop rotation, mulching, organic fertilizer) and use of improved varieties among others.

Rice farmers in Benue State were also reported by lke, and Mbah (2016) to use mixed cropping, zero tillage, adjustment of planting dates, crop rotation, diversification in crop and livestock production, improved land management techniques, early planting and early harvesting of rice, among others.

\section{Effect of Climate Change Adaptation Practices on Farmers' Level of Living}

Rice farmers' level of living was analysed through the amount of rice income spent on acquiring assets. It also determined the relationship between farmers' use of climate change adaptation practices and their level of living. 
Creative Commons User License: CC BY-NC-ND

Abstracted by: EBSCOhost, Electronic Journals Service (EJS), Google Scholar, Journal Seek, Scientific Commons,

Food and Agricultural Organization (FAO), CABI and Scopus
Journal of Agricultural Extension

Vol. 24 (3) July, 2020

ISSN(e): 24086851; ISSN(Print); 1119944X

http://journal.aesonnigeria.org

http://www.ajol.info/index.php/jae

Email: editorinchief@aesonnigeria.org

Rice farmers' level of living was analysed in terms of estimated amount of money spent on assets acquired after the production season under review (2015). The assets included vehicles, electronics and land and housing. Asset ownership is often used as a key welfare indicator. Asset acquisition may reflect an improvement in living standards and vice versa.

Estimated amount spent on acquiring vehicles: About $49 \%$ of the rice farmers did not spend any part of their rice income on vehicles. Among those who spent part of their rice income on vehicles, about $48 \%$ had spent within $\mathrm{A} 5,000-\mathrm{N} 126,999$, with $39 \%$ of them in Kebbi State, $59 \%$ in Sokoto State and $57 \%$ in Zamfara State. Only about $2 \%$ and $1 \%$ of the farmers spent within $\$ 127,000-\mathrm{N} 248,999$ and $\mathbf{N 2 4 9 , 0 0 0 -}$ N370,999 on vehicles, respectively (Table 3). This indicates that many of the farmers had spent part of their rice income on purchase of vehicles. Vehicles are important assets to farmers, not only for luxury, but essentially for transportation in the farming business. The story of an adequate farm management begins and ends with efficient and properly managed transport. Mechanized transport takes a very important place in every industry including agriculture (Hajdu, 2020). Hence, the use of climate change adaptation practices can lead to acquisition of vehicles which improves farming as a business and farmers' level of living.

Estimated amount spent on acquiring electronics: Some amount of money was also spent on electronics mostly for domestic use. About $46 \%$ of the rice farmers did not spend any part of their rice income on electronics. Among those who spent part of their rice income on electronics, $45 \%$ had spent within $1800-131,2999$, with $39 \%$ of them in Kebbi State, 52\% in Sokoto State and55\% in Zamfara State. Only 7\% and

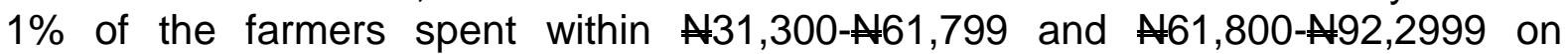
electronics, respectively (Table 3 ). This implies that many of the farmers had also spent part of their rice income on electronics. Electronics are important in making the life of farmers easier. They also contribute a lot in improving agriculture as a business. Kapoor, (2019) stated that there have been many new electronic types of equipment and components in the market, making way for smarter living. Among the many industries which have benefited from evolved electronics, agriculture is definitely on the top. It also indicates that the use of climate change adaptation practices had improve the farmers' use of electronics, hence, had a positive effect on their level of living.

Estimated amount spent on land and housing: The majority (about $86 \%$ ) of the rice farmers did not spend any part of their rice income on land and housing. Among those who spent part of their rice income on land and housing, $9.00 \%$ had spent within $\mathrm{N} 4,000-\mathrm{N} 36,999$, with $8 \%$ of them in Kebbi State, $5 \%$ in Sokoto State and $27 \%$ in Zamfara State. Only $4 \%$ and $1 \%$ of the farmers spent within 137,000 N69,999 and $\mathbf{A} 70,000-\mathrm{N} 102,999$ on land and housing, respectively (Table 3). This implies that very few of the farmers spent part of their rice income on land and housing. Land is an indispensable resource in agricultural production. Its access is fundamentally crucial to efficient agricultural production, food security and poverty alleviation in Sub-Saharan Africa where rural households have limited access to productive land (Akinyemi et al., 2019). 
Creative Commons User License: CC BY-NC-ND

Abstracted by: EBSCOhost, Electronic Journals Service (EJS), Google Scholar, Journal Seek, Scientific Commons,

Food and Agricultural Organization (FAO), CABI and Scopus

http://eoi.citefactor.org/10.11226/v24i3
Journal of Agricultural Extension

Vol. 24 (3) July, 2020

ISSN(e): 24086851; ISSN(Print); 1119944X

http://journal.aesonnigeria.org

http://www.ajol.info/index.php/jae

Email: editorinchief@aesonnigeria.org

Grundon (2016) asserted that owning a home is more than just hype; it is the gateway to long-term and short-term financial success. Long-term, you'll build an equity nest egg and short-term, you'll be able to enjoy potential tax breaks and pay yourself instead of a landlord. A home purchase is an investment you'll be glad you made! Grundon (2016) added that Owning a home can make a huge difference for your financial future, especially for a first-time homebuyer. While buying a home can be a transformative experience for you personally, homeownership can help you financially as well. Homeownership can lead to building your personal wealth due to home equity, or fair market value, which will likely increase over time based on both the market and any renovations you make to your home.

The idea behind adaptation activity is to reduce climate change-induced damages (Lazkano et al. 2016). Reduction in such damages could lead to increase in rice yield and farmers' income, hence improvement in their level of living.

Table 3: Rice farmers level of living

\begin{tabular}{|c|c|c|c|c|}
\hline $\begin{array}{l}\text { Estimated values of assets } \\
\text { acquired (N) }\end{array}$ & $\begin{array}{c}\begin{array}{c}\text { Kebbi } \\
\text { State } \\
(n=279) \\
\%\end{array} \\
\end{array}$ & $\begin{array}{r}\text { Sokoto } \\
\text { State } \\
(n=187) \\
\%\end{array}$ & $\begin{array}{c}\text { Zamfara } \\
\text { State } \\
(n=56) \\
\%\end{array}$ & $\begin{array}{c}\text { Pooled } \\
\text { Sample } \\
(n=522) \\
\% \\
\end{array}$ \\
\hline \multicolumn{5}{|l|}{$\begin{array}{l}\text { Estimated amount spent on } \\
\text { vehicles }\end{array}$} \\
\hline None & 56.99 & 39.57 & 42.86 & 49.23 \\
\hline 5000-126999 & 38.71 & 58.82 & 57.14 & 47.89 \\
\hline $127000-248999$ & 3.94 & 0.00 & 0.00 & 2.11 \\
\hline $249000-370999$ & 0.36 & 1.61 & 0.00 & 0.77 \\
\hline \multicolumn{5}{|l|}{$\begin{array}{l}\text { Estimated amount spent on } \\
\text { electronics }\end{array}$} \\
\hline None & 50.54 & 43.85 & 33.93 & 46.36 \\
\hline $800-31299$ & 39.07 & 52.41 & 53.57 & 45.40 \\
\hline 31300-61799 & 9.32 & 2.67 & 10.71 & 7.09 \\
\hline 61800-92299 & 1.08 & 1.07 & 1.79 & 1.15 \\
\hline \multicolumn{5}{|c|}{$\begin{array}{l}\text { Estimated amount spent on land } \\
\text { and housing }\end{array}$} \\
\hline None & 87.81 & 90.91 & 64.29 & 86.40 \\
\hline 4000-36999 & 7.89 & 5.35 & 26.79 & 9.00 \\
\hline 37000-69999 & 3.58 & 3.74 & 7.14 & 4.02 \\
\hline 70000-102999 & 0.72 & 0.00 & 1.79 & 0.58 \\
\hline
\end{tabular}

\section{Relationship Between Use of Climate Change Adaptation Practices and Level of Living}

Relationship between farmers' use of climate change adaptation practices and their level of living was analysed. The farmers' level of living was measured as the value of assets acquired by the rice farmers. The analysis revealed a significant $(p \leq 0.00)$ relationship between farmers' use of climate change adaptation practices and their 
Creative Commons User License: CC BY-NC-ND

Abstracted by: EBSCOhost, Electronic Journals Service (EJS), Google Scholar, Journal Seek, Scientific Commons,

Food and Agricultural Organization (FAO), CABI and Scopus
Journal of Agricultural Extension

Vol. 24 (3) July, 2020

ISSN(e): 24086851; ISSN(Print); 1119944X

http://journal.aesonnigeria.org

http://www.ajol.info/index.php/jae

Email: editorinchief@aesonnigeria.org

level of living with a chi-square value of 258.6325. This implies the existence of a strong relationship between the rice farmers' use of climate change adaptation practices and their level of living. Hence, the null hypothesis, which states that there is no significant relationship between use of climate change adaptation practices and farmers' level of living, is rejected. Farmers should therefore utilize the climate change adaptation practices for improvement in their level of living.

Farmers' assets base is largely determined by their income level. The income level of the farmers is in turn negatively affected by climatic variations as observed by Cervantes-Godoy et al. (2013) that agricultural production hazards largely affect the income of farmers. Use of the climate change adaptation practices by the rice farmers improves their yields and income as reported by Ojo and Baiyegunhi (2019) who reported that average net income per rice farm of farmers in south-west Nigeria who used the climate change adaptation strategies was significantly higher than that of those who did not.

\section{Conclusion and Recommendations}

Portfolio diversification (use of improved rice varieties and intercropping), soil conservation (moderate use of fertilizers, moderate use of chemicals and use of organic manure), adjusting the planting calendar (early planting and early harvesting), minimum tillage (making mounds and digging ridges across slopes) and use of irrigation technologies (use of rivers/streams and digging of well) by the farmers could lower the adverse effect of climate change on rice production. Hence, these climate change adaptation practices had led to improvement in the farmers level of living through increase in income and assets acquisition.

There should be an awareness creation campaign by both governments and nongovernmental organizations concerned with agricultural development to educate the farmers on the importance of mulching, planting of cover crops, trees for soil conservation and indeed all the climate change adaptation practices especially among the low users, since their use was found to be associated with improvement in the farmers' level of living through increase in income assets acquisition.

\section{References}

Abaje, I.B.; Sawa, B.A. and Ati, O.F. (2014). Climate variability and change, impacts and adaptation strategies in Dutsinma Local Government Area of Katsina State, Nigeria; Journal of Geography and Geology; 6(2): 68-72.

Adebayo, A.A.; Onu, J.I.; Adebayo, E.F. and Anyanwu, S.O. (2012). Farmers' awareness, vulnerability and adaptation to climate change in Adamawa State, Nigeria; British Journal of Arts and Social Sciences 9(2):104-115.

Akintonde, J.O. Lwasa S. and Purnamita D (2016). Assessment of level of use of climate change adaptation strategies among arable crop farmers in Oyo and Ekiti States, Nigeria, Journal of Earth Science \& Climatic Change, (7):369. 
Creative Commons User License: CC BY-NC-ND

Abstracted by: EBSCOhost, Electronic Journals Service (EJS), Google Scholar, Journal Seek, Scientific Commons,

Food and Agricultural Organization (FAO), CABI and Scopus

http://eoi.citefactor.org/10.11226/v24i3
Journal of Agricultural Extension

Vol. 24 (3) July, 2020

ISSN(e): 24086851; ISSN(Print); 1119944X

http://journal.aesonnigeria.org

http://www.ajol.info/index.php/jae

Email: editorinchief@aesonnigeria.org

Akinyemi, B.E., Mushunje, A. and Sinnett, D. (2019). Land ownership and usage for agriculture: Empirical evidence from South African Living Conditions Survey, Cogent Social Sciences, 5(1): 1-18

Ali, S., Liu, Y., Ishaq, M., Shah, T., Ilyas, A.A. and Din, I.U. (2017). Climate Change and Its Impact on the Yield of Major Food Crops: Evidence from Pakistan, Foods, 6(6):39

Arimi, K., (2014). Determinants of Climate Change Adaptation Strategies Used by Rice Farmers in Southwestern, Nigeria; Journal of Agriculture and Rural Development in the Tropics and Subtropics, 115 (2): 91-99.

Cervantes-Godoy, D., Kimura, S. and Antón, J., (2013). Smallholder risk management in developing countries, OECD Food, Agriculture and Fisheries Papers, No. 61. OECD Publishing

Erbas, B.C. and Solakoglu, E.G. (2017). In the Presence of Climate Change, the Use of Fertilizers and the Effect of Income on Agricultural Emissions, Sustainability, 9(1989): 1-17

Grundon, M. (2016). Why Owning a Home Is Important, Available at https://www.missionfed.com/blog/why-owning-home-important\#gref, Accessed 25/04/2020.

Hajdu, I. (2020). Transport as an Important Factor for a Farmer's Success, Available at https://blog.agrivi.com/post/transport-as-an-important-factor-for-a-farmer-ssuccess, sourced: 24/04/2020.

Ho, T.T. and Shimada, K. (2018). The impact of climate change adaptation response on rice farmers' livelihood in Soc Trang province of Vietnam, International Journal of Food and Agricultural Economics, 6(3): 11-31.

Ike, E.C. and Mbah, E.N. (2016). Climate Change Adaptation Measures Practiced by Rice Farmers in Benue State, Nigeria, International Journal of Trend in Research and Development, 3(1): 1-6.

Kapoor, R. (2019). What is the role of electronics in agriculture? Available at https://www.airtract.com/question/What-is-the-role-of-electronics-inagriculture, accessed: 24/04/2020

Lazkano, I., Marrouch, W. and Nkuiya, B. (2016). Adaptation to Climate Change: How Does Heterogeneity in Adaptation Costs affect Climate Coalitions? Environment and Development Economics (21): 812-838. https://doi.org/10.1017/S1355770X16000097.

Lewis, P., Monem, M.A. and Impiglia, A. (2018). Impacts of climate change on farming 
Creative Commons User License: CC BY-NC-ND

Abstracted by: EBSCOhost, Electronic Journals Service (EJS), Google Scholar, Journal Seek, Scientific Commons,

Food and Agricultural Organization (FAO), CABI and Scopus

http://eoi.citefactor.org/10.11226/v24i3
Journal of Agricultural Extension

Vol. 24 (3) July, 2020

ISSN(e): 24086851; ISSN(Print); 1119944X

http://journal.aesonnigeria.org

http://www.ajol.info/index.php/jae

Email: editorinchief@aesonnigeria.org

systems and livelihoods in the near east and North Africa - With a special focus on small-scale family farming. Cairo, FAO. 92 pp. Licence: CC BY-NC-SA 3.0 IGO.

National Population Commission (NPC) (2015). Federal Republic of Nigeria, 2006

Population Census. National Population Commission, www.nigerianstat.gov.ng.

Nwaobiala C.U. and Adesope O.M. (2013). Economic Analysis of Small Holder Rice Production Systems in Ebonyi State South East, Nigeria, Russian Journal of Agricultural and Socio-Economic Sciences, 11(23): 1-8.

Ojo, T.O. and Baiyegunhi, L.J.S. (2019). Determinants of climate change adaptation strategies and its impact on the net farm income of rice farmers in south-west Nigeria, Available at https://doi.org/10.1016/j.landusepol.2019.04.007, Access: 26/04/2020.

Richards, M., Sapkota, T., Stirling, C., Thierfelder, C., Verhulst, N., Friedrich, T. and Kienzle, J. (2014). PracticeBrief Climate-smart agriculture; FAO/D. Hayduk Implementation guidance for policymakers and investors.

Yakubu, D.H., Abubakar, B.Z., Atala, T.K. Muhammed, A. and Abdullahi, M.K. (2013). Assessing the effects of socio-economic factors on ICTs adoption among extension workers in the north-west zone of Nigeria. International Journal of Agricultural Policy and Research, 1(9): 255-269. 